\title{
Sistem Pakar Mendeteksi Kerusakan ECU (Electronic Control Unit) pada Motor Injeksi Honda PCX di PT. Supra Jaya Abadi Titi Kuning Medan dengan Metode Certainty Factor
}

\author{
Rinal Trisnawan *, Ahmad Fitri Boy ", Ita Mariami ${ }^{*}$ \\ "Program Studi Sistem Informasi, STMIK Triguna Dharma
}

\begin{abstract}
Abstrak
Mengingat tingginya pengguna sepeda motor matic injeksi saat ini timbul permasalahan bahwa tidak semua pengguna motor matic injeksi memiliki kemampuan untuk memperbaiki kerusakan sepeda motornya. Pengguna lebih mempercayakan masalah itu pada mekanik bengkel. Beberapa jenis kerusakan yang ada pada mesin sepeda motor injeksi salah satunya adalah kerusakan pada ECU (Electronic Control Unit). ECU (Electronic Control Unit) adalah sebuah perangkat elektronik yang berfungsi untuk mengatur operasi dari internal combustion engine(mesin pembakaran).

Untuk Mengatasi permasalahan tersebut dalam penelitian ini akan dibangun sistem yaitu Sistem Pakar dengan menggunakan sebuah metode yaitu metode Certainty Factor untuk mendeteksi kerusakan berdasarkan nilai MB ( Measure of Beliefe) dan MD ( Measure of Disbeliefe) dari gejala-gejala kerusakan yang terlihat pada kendaraan. Nilai Certainty Factor digunakan untuk menentukan kerusakan berdasarkan rules yang telah ditentukan, serta mengetahui seberapa besar persentase keberhasilan diagnosa kerusakan dengan menggunakan metode Certainty Factor.

Dalam masalah yang dibahas pada penelitian ini akan di rancang sebuah perangkat lunak berbasis desktop yang diharapkan menjadi solusi pemecahan masalah. Hasil penelitian merupakan terciptanya sebuah aplikasi Sistem Pakar dengan Metode Certainty Factor yang dapat membantu untuk mendiagnosa kerusakan ECU pada mesin motor injeksi.
\end{abstract}

Kata kunci : Sistem Pakar, Kerusakan ECU(Electronic Control Unit), Certainty Factor.

\section{Abstract}

Given the high number of injection matic motorbike users, the problem arises that not all injection matic motorbike users have the ability to repair damaged motorbikes. Users entrust the problem more to the mechanic of the workshop. Several types of damage exist in injection motorcycle engines, one of which is damage to the ECU (Electronic Control Unit). ECU (Electronic Control Unit) is an electronic device which functions to regulate the operation of the internal combustion engine (combustion engine).

To overcome these problems in this study a system will be built, namely the Expert System using a method, namely the Certainty Factor method to detect damage based on the MB (Measure of Beliefe) and MD (Measure of Disbeliefe) values of the symptoms of damage seen on the vehicle. The Certainty Factor value is used to determine damage based on predetermined rules, as well as to find out the percentage of success in diagnosing damage using the Certainty Factor method.

In the problems discussed in this study, a desktop-based software will be designed which is expected to be a problem-solving solution. The result of this research is the creation of an Expert System application with the Certainty Factor Method which can help to diagnose damage to the ECU on an injection motor engine.

Keywords : Expert System, Faulty ECU (Electronic Control Unit), Certainty Factor 


\section{PENDAHULUAN}

Sepeda Motor merupakan salah satu alat transportasi yang sangat digemari oleh masyarakat Indonesia. Dari tahun ke tahun pengendara sepeda motor di Indonesia semakin meningkat, terutama untuk sepeda motor matic injeksi. Pada pertengahan tahun 2020 saja data dari Asosiasi Industri Sepeda Motor Indonesia (AIDI) Mencatat telah terjual sebanyak 1.454 .792 unit dimana jenis sepeda motor matic injeksi terjual 1.276 .175 unit dengan persentase penjualan $(87,7 \%)$. Injeksi merupakan suatu metode pencampuran bahan bakar dengan udara pada kendaraan bermotor untuk menghasilkan pembakaran yang sempurna. Injeksi membutuhkan sebuah perangkat bernama injector, yang bertugas menyuplai campuran bahan bakar dengan udara. Sistem Injeksi merupakan teknologi penerus system karburator pada kendaraan bermotor [1]. Mengingat tingginya pengguna sepeda motor matic injeksi saat ini timbul permasalahan bahwa tidak semua pengguna motor matic injeksi memiliki kemampuan perbaikan terhadap kerusakan sepeda motornya. Pengguna lebih mempercayakan masalah itu pada mekanik bengkel[2].

Ada beberapa jenis kerusakan yang ada pada mesin sepeda motor injeksi salah satunya adalah kerusakan pada ECU (Electronic Control Unit). ECU (Electronic Control Unit) adalah sebuah perangkat elektronik yang berfungsi untuk mengatur operasi dari internal combustion engine(mesin pembakaran dalam). Manfaat menggunakan ECU ini akan menyebabkan waktu pengapian dan penyemprotan bahan bakar lebih presisi[3]. Selain dengan teknik pemeriksaan langsung ke bengkel ada beberapa teknik yang dapat digunakan untuk medeteksi kerusakan pada ECU (Electronic Control Unit) salah satunya dengan teknik Sistem Pakar. .

Sistem Pakar (expert system) merupakan sistem yang berusaha mengadopsi kemampuan atau pengetahuan manusia ke dalam komputer, agar computer dapat bekerja dalam menyelesaikan suatu masalah seperti layaknya seorang pakar atau seseorang yang mempunyai keahlian dalam bidang tertentu, yaitu pakar yang mempunyai knowledge atau kemampuan khusus yang tidak diketahui dan dimiliki oleh orang lain. Sistem Pakar merupakan cabang dari Artificial Intelligence(AI)[4]. Salah satu metode pada sistem pakar ialah algoritma Certainty Factor. Certainty Factor merupakan suatu metode untuk membuktikan ketidakpastian pemikiran seorang pakar, dimana untuk mengakomodasi hal tersebut seseorang biasanya menggunakan metode certainty factor untuk menggambarkan keyakinan seorang pakar terhadap masalah yang sedang di hadapi [5]. Hasil metode certainty factor yang berupa persentase, cocok untuk hasil program yang dibutuhkan pada penelitian.

Dari latar belakang diatas, maka diangkat sebuah penelitian dengan judul "Sistem Pakar Mendeteksi Kerusakan ECU (Electronic Control Unit) pada Motor Injeksi Honda PCX di PT. Supra Jaya Abadi Titi Kuning Medan dengan Metode Certainty Factor".

\section{KAJIAN PUSTAKA}

\subsection{Pengertian Sistem Pakar}

Sistem pakar merupakan suatu program yang sengaja dibuat dengan tujuan untuk mendapatkan suatu kesimpulan, jawaban atau solusi yang mendekati atau mirip dengan seorang pakardalam bidang tertentu[6]. Sistem pakar adalah sistem berbasis komputer yang menggunakan pengetahuan, fakta dan teknik penalaran dalam memecahkan masalah yang biasanya hanya dapat dipecahkan oleh seorang pakar dalam bidang tersebut[7].

\subsection{Algoritma Certainty Factor}

Teori Certainty Factor (CF) adalah untuk mengakomodasi ketidakpastian pemikiran (inexact reasoning) seorang pakar yang di usulkan oleh Shortliffe dan Buchanan pada tahun 1975. Faktor kepastian (certainty factor) menyatakan kepercayaan dalam sebuah kejadian (fakta atau hipotesa) berdasar bukti atau penilaian pakar. Certainty factor menggunakan suatu nilai untuk mengasumsikan derajat keyakinan seorang pakar terhadap suatu data (Nella Almi Ritonga. 2013). Metode certainty factor digunakan ketika menghadapi suatu masalah yang jawabannya tidak pasti. Ketidakpastian ini bisa merupakan probabilitas ( Stephanie Halim, Seng Hansun. 2015)[8]. 
Metode certainty factor mengukur sesuatu yang pasti atau tidak pasti dengan pengambilan keputusan, sebuah representasi grafis dari keyakinan dalam krangka probabilistik. Certainty factor memperkenalkan konsep belief/keyakinan dan disbelief/ketidakyakinan. Konsep ini diformulasikan dalam Rumus dasar CF sebagai berikut [11].

$\mathrm{CF}[\mathrm{H}, \mathrm{E}]=\mathrm{MB}[\mathrm{H}, \mathrm{E}]-\mathrm{MD}[\mathrm{H}, \mathrm{E}]$

Keterangan :

$\mathrm{CF} \quad=$ Certainty factor berarti hipotesis $\mathrm{H}$ yang dipengaruhi oleh fakta $\mathrm{E}$.

$\mathrm{MB}$ = Measure of Belief (tingkat keyakinan), merupakan tingkat kenaikan dari kepercayaan hipotesisH dipengaruhi oleh fakta $\mathrm{E}$.

$\mathrm{MD}=$ Measure of Disbelief (tingkat ketidakyakinan) merupakan kenaikan dari ketidakpastian hipotesis

$\mathrm{H} \quad=$ Hipotesis $\mathrm{H}$ dipengaruhi oleh fakta $\mathrm{E}$.

$\mathrm{E} \quad=$ Evidence Peristiwa atau fakta.

Perhitungan Certainty Factor

Secara umum rule atau aturan direpresentasikan dalam bentuk sebagai berikut :

IF E1 AND E2......AND En THEN H (CF Rule) atau

IF E1 OR E2 ....... OR En THEN H (CF Rule)....

Keterangan :

E1.... E2 : Fakta-fakta (evidence) yang ada

$\mathrm{H} \quad$ : Hipotesis atau konklusi yang dihasilkan

CF Rule $\quad$ : Tingkat kayakinan terjadinya hipotesis $\mathrm{H}$ adanya fakta- fakta $\mathrm{E} 1$.....E2

Rule dengan evidence $E$ tunggal dan hipotesis $\mathrm{H}$ tunggal IF E1 AND E2 ......AND En THEN H (CF Rule) $\mathrm{CF}(\mathrm{H}, \mathrm{E})=\mathrm{CF}(\mathrm{E}) \times \mathrm{CF}$ (Rule)

Rule dengan evidence $\mathrm{E}$ ganda dan hipotesis $\mathrm{H}$ tunggal IF E1 AND E2 ......AND En THEN $\mathrm{H}$ (CF Rule) $\mathrm{CF}(\mathrm{H}, \mathrm{E})=\min [\mathrm{CF}(\mathrm{E} 1), \mathrm{CF}(\mathrm{E} 2), \ldots, \mathrm{CF}(\mathrm{En})] \times \mathrm{CF}($ rule) IF E1 OR E2 OR En THEN $\mathrm{CF}(\mathrm{H}, \mathrm{E})=\max [\mathrm{CF}(\mathrm{E} 1), \mathrm{CF}(\mathrm{E} 2), \ldots, \mathrm{CF}(\mathrm{En})] \times \mathrm{CF}($ rule $)$

Kombinasi dua buah rule dengan evidence berbeda (E1 dan E2), tetapi hipotesisnya sama.

IF E1 THEN H Rule $1 \quad \mathrm{CF}(\mathrm{H}, \mathrm{E} 1)=\mathrm{CF} 1=\mathrm{C}(\mathrm{E} 1) \times \mathrm{CF}$ (rule 1)

IF E2 THEN H Rule $2 \quad \mathrm{CF}(\mathrm{H}, \mathrm{E} 2)=\mathrm{CF} 2=\mathrm{C}(\mathrm{E} 2) \times \mathrm{CF}($ rule 2)

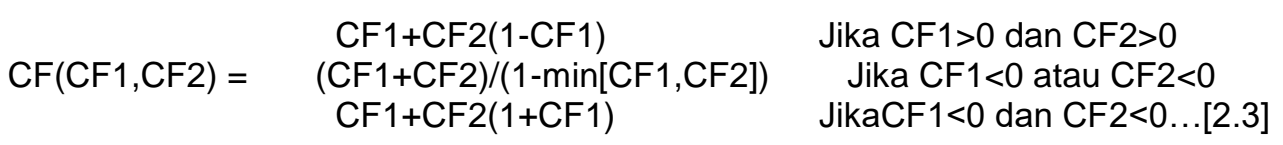

\section{METODOLOGI PENELITIAN DAN HASIL}

\subsection{Metode Penelitian}

1. Observasi

Obervasi merupakan teknik pengumpulan data dengan melakukan tinjauan langsung ke tempat studi kasus dimana akan dilakukan penelitian. Dalam hal ini dilakukan obervasi di Bengkel Resmi PT. Supra Jaya Abadi Titi Kuning Medan untuk mengetahui masalah apa yang akan terjadi terkait masalah kerusakan pada ECU (Electronic Control Unit) dengan melakukan tinjauan langsung.

2. Wawancara

Wawancara adalah suatu cara pengumpulan data yang dilakukan dengan mengadakan tanya jawab secara langsung dengan Teknisi. di Bengkel Resmi PT. Supra Jaya Abadi Titi Kuning Medan untuk memperoleh informasi mengenai masalah kerusakan ECU pada Motor Injeksi, tentang gejala, penanggulangan dan perbaikan.

Berdasarkan wawancara yang dilakukan berikut adalah jenis kerusakan ECU pada Motor Injeksi yang dibahas pada penelitian ini dapat dilihat pada tabel berikut : 
Tabel 3.1 Data Jenis Kerusakan ECU pada Motor Injeksi

\begin{tabular}{|c|l|}
\hline Kode Kerusakan & Kerusakan ECU pada Motor Injeksi \\
\hline K001 & ECU Memory Error \\
\hline K002 & Fuel Injector Sensor \\
\hline K003 & Coolant Temperature Sensor \\
\hline K004 & Crankshaft Position Sensor \\
\hline K005 & Throtle Position Sensor \\
\hline
\end{tabular}

Berdasarkan wawancara yang dilakukan berikut adalah Nilai Probabilitas Gejala kerusakan ECU pada motor injeksi yang dibahas pada penelitian ini dapat dilihat pada tabel berikut :

Tabel 3.3 Nilai Probabilitas Gejala Kerusakan

\begin{tabular}{|c|c|c|c|c|c|c|}
\hline \multirow{2}{*}{ No } & \multirow{2}{*}{ Gejala } & \multicolumn{5}{|c|}{ Kemungkinan } \\
\hline & & P01 & P02 & P03 & P04 & P05 \\
\hline 1 & $\begin{array}{c}\text { Kontak MIL (Malfunction Indicator Lamp) } \\
\text { Menyala }\end{array}$ & 0,8 & 0,8 & 0,8 & 0,8 & 0,8 \\
\hline 2 & $\begin{array}{c}1 \text { Kedipan Panjang Pada MIL(Malfunction } \\
\text { Indicator Lamp) }\end{array}$ & & & 0,7 & 0,7 & 0,7 \\
\hline 3 & $\begin{array}{c}3 \text { Kedipan Panjang Pada MIL(Malfunction } \\
\text { Indicator Lamp) }\end{array}$ & & 0,7 & & & \\
\hline 4 & $\begin{array}{c}5 \text { Kedipan Panjang Pada MIL(Malfunction } \\
\text { Indicator Lamp) }\end{array}$ & 0,7 & & & & \\
\hline 5 & $\begin{array}{l}1 \text { Kedipan Pendek Pada MIL(Malfunction } \\
\text { Indicator Lamp) }\end{array}$ & & 0,7 & 0,6 & & \\
\hline 6 & $\begin{array}{l}3 \text { Kedipan Pendek Pada MIL(Malfunction } \\
\text { Indicator Lamp) }\end{array}$ & & & & 0,6 & \\
\hline 7 & $\begin{array}{c}7 \text { Kedipan Pendek Pada MIL(Malfunction } \\
\text { Indicator Lamp) }\end{array}$ & & & & & 0,6 \\
\hline 8 & Muncul kode error pada tampilan speedometer & 0,6 & & & & \\
\hline 9 & Panas berlebihan pada mesin & & & 0,6 & & \\
\hline 10 & Motor tidak bisa hidup & 0,7 & 0,6 & & 0,6 & 0,6 \\
\hline 11 & Boros Bahan Bakar & & 0,7 & 0,7 & & \\
\hline 12 & Mesin Tersendat-sendat & & 0,6 & & 0,6 & \\
\hline
\end{tabular}

Sumber : Mekanik PT. Supra Jaya Abadi Titi

\section{Kuning Medan}

Berdasarkan wawancara yang dilakukan berikut adalah Kesimpulan Gejala Kerusakan ECU pada Motor Injeksi yang dibahas pada penelitian ini dapat dilihat pada tabel berikut : Tabel 3.4 Kesimpulan Gejala Kerusakan ECU pada Motor Injeksi

\begin{tabular}{|l|l|l|l|}
\hline Rule & IF & Then & Keterangan \\
\hline 1 & G1,G4,G8,G10 & K001 & ECU Memory Error \\
\hline
\end{tabular}




\begin{tabular}{|l|l|l|l|}
\hline 2 & G1,G3,G5,G10,G11,G12 & K002 & Fuel Injector Sensor \\
\hline 3 & G1,G2,G5,G9,G11 & K003 & Coolant Temperature Sensor \\
\hline 4 & G1,G2,G6,G10,G12 & K004 & Crankshaft Position Sensor \\
\hline 5 & G1,G2,G7,G10 & K005 & Throtle Position Sensor \\
\hline
\end{tabular}

Sumber : Mekanik PT. Supra Jaya Abadi Titi Kuning Medan

Tabel 3.5 Nilai MB dan MD Gejala Kerusakan

\begin{tabular}{|c|c|c|c|}
\hline $\begin{array}{c}\text { Nama } \\
\text { Penyakit }\end{array}$ & Nama Gejala & $\begin{array}{c}\text { MB } \\
\text { (Measure of Beliefe) }\end{array}$ & $\begin{array}{c}\text { MD } \\
\text { (Measure of Disbeliefe) }\end{array}$ \\
\hline \multirow{4}{*}{ K001 } & G1 & 0,8 & 0,2 \\
\hline & G4 & 0,7 & 0,3 \\
\hline & G8 & 0,6 & 0,4 \\
\hline & G10 & 0,7 & 0,3 \\
\hline \multirow{6}{*}{ K002 } & G1 & 0,8 & 0,2 \\
\hline & G3 & 0,7 & 0,3 \\
\hline & G5 & 0,7 & 0,3 \\
\hline & G10 & 0,6 & 0,4 \\
\hline & G11 & 0,7 & 0,3 \\
\hline & G12 & 0,6 & 0,4 \\
\hline \multirow{5}{*}{ P003 } & $\mathrm{G} 1$ & 0,8 & 0,2 \\
\hline & G2 & 0,7 & 0,3 \\
\hline & G5 & 0,6 & 0,4 \\
\hline & G9 & 0,6 & 0,4 \\
\hline & G11 & 0,7 & 0,3 \\
\hline \multirow{5}{*}{ K004 } & G1 & 0,8 & 0,2 \\
\hline & G2 & 0,7 & 0,3 \\
\hline & G6 & 0,6 & 0,4 \\
\hline & G10 & 0,6 & 0,4 \\
\hline & G12 & 0,6 & 0,4 \\
\hline \multirow{4}{*}{ K005 } & G1 & 0,8 & 0,2 \\
\hline & G2 & 0,7 & 0,3 \\
\hline & G7 & 0,6 & 0,4 \\
\hline & G10 & 0,6 & 0,4 \\
\hline
\end{tabular}

\subsubsection{Perhitungan Certainty Factor}

Untuk merancang aplikasi sistem pakar mendiagnosa jenis kerusakan ECU pada motor injeksi menggunakan metode certainty factor dapat teruji kebenarannya, maka digunakan datadata pasien dengan menghitung nilai CF dari beberapa jenis kerusakan yang pernah ditangani oleh Mekanik Resmi Honda, sebagai seorang pakar yang pernah menangani Pelanggan yang menderita kerusakan ECU pada motor injeksi.

1. Menentukan Gejala

Pelanggan 1 bernama Maulana konsultasi dengan mekanik tentang gejala- gejala kerusakan ECU motor yang dialaminya seperti : Kontak MIL(Malfuction Indicator Lamp) menyala (G1), 5 Kedipan Panjang Pada MIL(Malfunction Indicator Lamp) (G4), 1 Kedipan Pendek Pada MIL(Malfunction Indicator Lamp) (G5), Motor tidak bias hidup (G10). Dibawah ini adalah tabel gejala pada pelanggan 1 sebagai berikut :

Berikut adalah sampel konsultasi dari kerusakan ECU pada motor injeksi : 
Tabel 3.6 Konsultasi Pelanggan

\begin{tabular}{|c|c|c|c|c|c|}
\hline \multirow{2}{*}{ Kode Gejala } & \multicolumn{2}{|l|}{ ECU Memory Error } & \multirow{2}{*}{ Kode Gejala } & \multicolumn{2}{|c|}{ Fuel Injector Sensor } \\
\cline { 5 - 6 } & MB & MD & & MB & MD \\
\hline G1 & 0,8 & 0,2 & G1 & 0,8 & 0,2 \\
\hline G4 & 0,7 & 0,3 & G5 & 0,7 & 0,3 \\
\hline G10 & 0,7 & 0,3 & G10 & 0,6 & 0,4 \\
\hline
\end{tabular}

2. Menghitung Nilai CF(certainty factor)

Berikut ini adalah perhitungan metode certainty factor untuk mencari jenis kerusakan ECU pada motor injeksi yang diderita oleh pelanggan 1 :

a. ECU Memory Error

Pertama hitung nilai CF untuk satu gejala :

$\mathrm{G} 1=$ Kontak MIL (Malfunction Indicator Lamp) Menyala. $\mathrm{MB}=0,8$;

$\mathrm{MD}=0,2, \mathrm{CF} 1=0,8-0,2=0,6$

G4 $=5$ Kedipan Panjang Pada MIL(Malfunction Indicator Lamp). MB $=0,7$;

$\mathrm{MD}=0,3, \mathrm{CF} 4=0,7-0,3=0,4$

$\mathrm{G} 10=$ Motor tidak bisa hidup. $\mathrm{MB}=0,7 ; \mathrm{MD}=0,3, \mathrm{CF} 10=0,7-0,3=0,4$

Selanjutnya hitung dengan Metode Certainty Factor lebih dari satu gejala :

$$
\begin{array}{ll}
\mathrm{CF}(\mathrm{CF} 1, \mathrm{CF} 4) & =\mathrm{CF} 1+\mathrm{CF} 4 \times(1-\mathrm{CF} 1) \\
& =0,6+0,4 \times(1-0,6)=0,6+(0,4 \times 0,4) \\
\mathrm{CF}(\mathrm{CF} 1, \mathrm{CF} 4, \mathrm{CF} 10) & =0,76 \\
& =\mathrm{CF}(\mathrm{F} 1, \mathrm{~F} 4)+\mathrm{CF} 10 \times(1-\mathrm{CF}(\mathrm{CF} 1, \mathrm{CF} 4)) \\
& =0,76+0,4 \times(1-0,76) \\
& =0,856
\end{array}
$$

b. Fuel Injector Sensor

Pertama hitung nilai CF untuk satu gejala :

$\mathrm{G} 1=$ Kontak MIL (Malfunction Indicator Lamp) Menyala. $\mathrm{MB}=0,8$;

$\mathrm{MD}=0,2, \mathrm{CF} 1=0,8-0,2=0,6$

$\mathrm{G} 5=1$ Kedipan Pendek Pada MIL(Malfunction Indicator Lamp). MB $=0,7 ; \mathrm{MD}=0,3, \mathrm{CF} 4$

$=0,7-0,3=0,4$

$\mathrm{G} 10=$ Motor tidak bisa hidup. $\mathrm{MB}=0,6 ; \mathrm{MD}=0,4, \mathrm{CF} 10=0,6-0,4=0,2$

Selanjutnya hitung dengan Metode Certainty Factor lebih dari satu gejala :

$$
\begin{array}{ll}
\mathrm{CF}(\mathrm{CF} 1, \mathrm{CF} 5) & =\mathrm{CF} 1+\mathrm{CF} 5 \times(1-\mathrm{CF} 1) \\
& =0,6+0,4 \times(1-0,6)=0,6+(0,4 \times 0,4) \\
\mathrm{CF}(\mathrm{CF} 1, \mathrm{CF} 5, \mathrm{CF} 10) & =0,76 \\
& =\mathrm{CF}(\mathrm{F} 1, \mathrm{~F} 4)+\mathrm{CF} 10 \times(1-\mathrm{CF}(\mathrm{CF} 1, \mathrm{CF} 5)) \\
& =0,76+0,2 \times(1-0,76) \\
& =0,808
\end{array}
$$

3. Hasil perhitungan metode certainty factor

Berikut ini adalah hasil perhitungan menggunakan metode Certainty Factor dari gejala kerusakan ECU yang dialami yaitu :

a. ECU Memory Error nilai CF adalah $=0,856$

b. Fuel Injector Sensor nilai CF adalah $=0,808$

Mencari nilai $\operatorname{Max}=(0,856):(0,808)$

$$
=0,856
$$

Dengan demikian dapat dikatakan bahwa perhitungan CF pada gejala kerusakan ECU motor injeksi memiliki persentase tingkat keyakinan $0,856 \times 100 \%=85,6 \%$ dan dilihat dari perhitungan diatas maka kemungkinan masalah kerusakan karena

ECU Memory Error.

\section{Implementasi Dan Pengujian}

Implementasi sistem merupakan hasil rancangan yang dibuat menjadi hasil implementasi perancangan form kedalam bahasa pemograman Visual. Berikut ini hasil sistem pakar 
mendiagnosa kerusakan ECU (Electronic Control Unit) pada mesin motor injeksi menggunakan algoritma Certainty Factor.

1. Form Login

Form login digunakan untuk mengamankan sistem dari user-user yang tidak bertanggung jawab. Pada form ini diharuskan mengisi User Id dan Password pada form login. adapun tampilan dari form login adalah seperti terlihat pada gambar berikut:

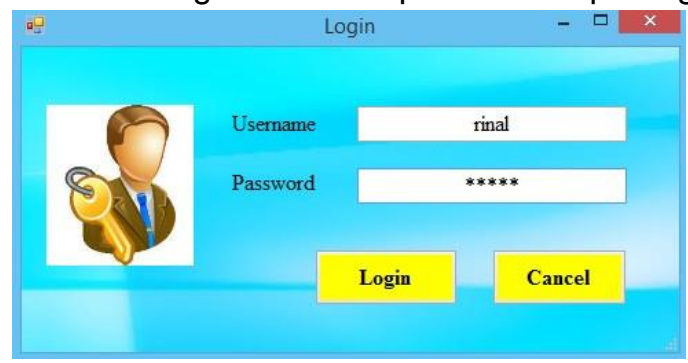

Gambar 4.1 Tampilan Form Login

\section{Form Menu Utama}

Form menu utama tampil apabila admin berhasil login pada aplikasi. Tampilan dari form utama dapat dilihat pada gambar berikut ini.

\section{Form Pelanggan}

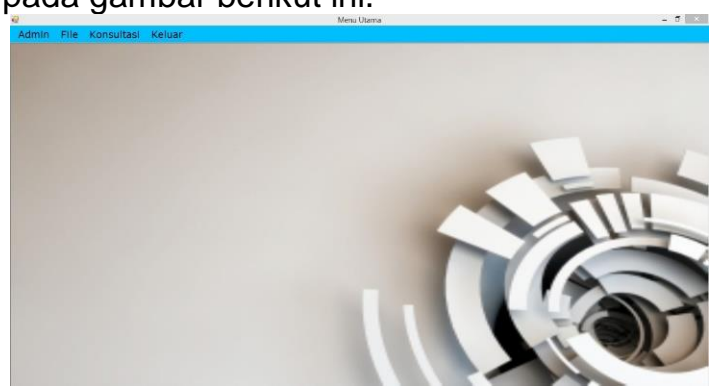

Gambar 4.2 Tampilan Form Menu Utama

Form Pelanggan digunakan untuk menambah data pelanggan ke dalam database. Adapun tampilan keluaran dari form Pelanggan adalah sebagai berikut :

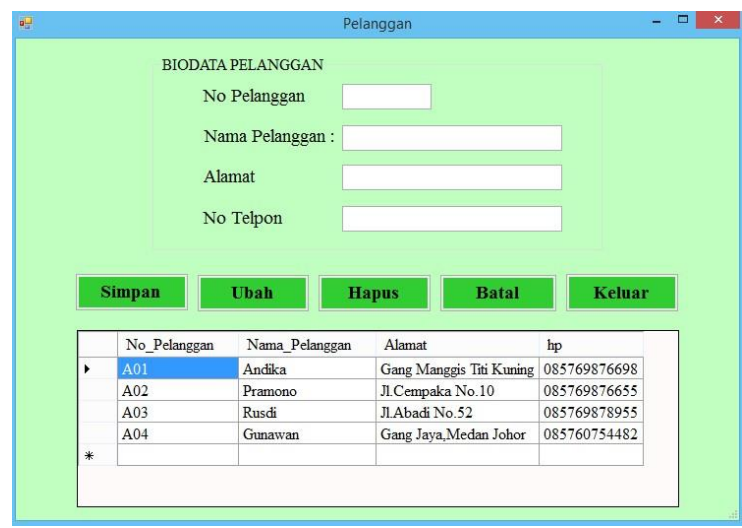

Gambar 4.3 Tampilan Form Pelanggan

\section{Form Gejala}

Form Gejala adalah form yang gunakan untuk mengelola Data Gejala yang ada pada sistem. Adapun tampilan keluaran dari form Gejala adalah sebagai berikut. 


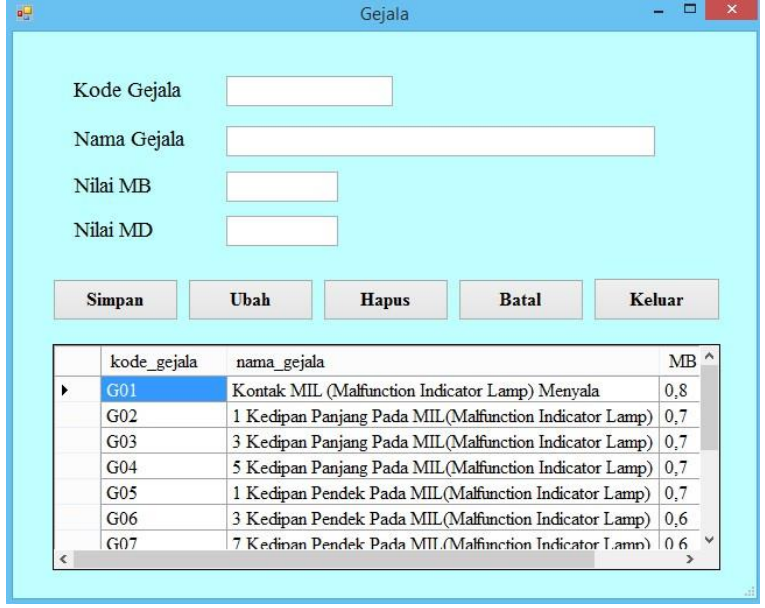

Gambar 4.4 Tampilan Form Gejala

\section{Form Kerusakan}

Form kerusakan digunakan untuk mengelola kerusakan pada sistem. Tampilan dari form kerusakan dapat dilihat pada gambar berikut ini :

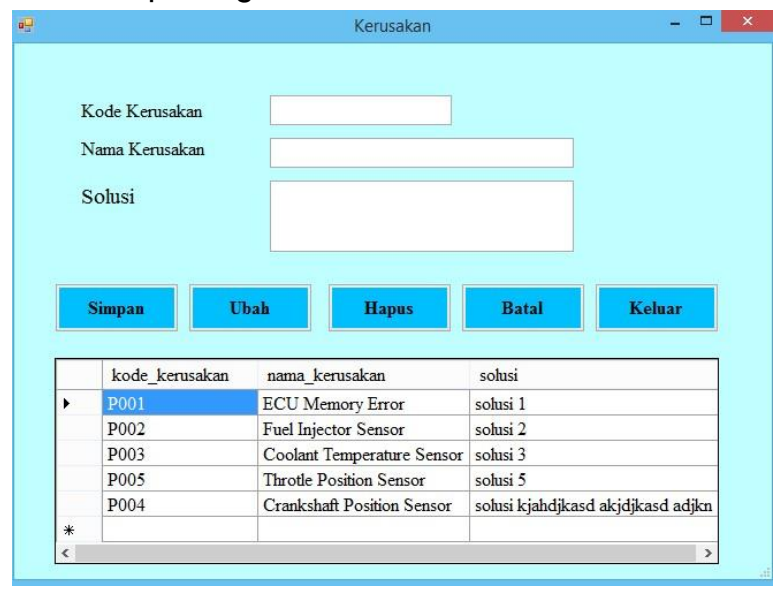

\section{Form Diagnosa}

Gambar 4.5 Tampilan Form Kerusakan

Form Diagnosa adalah form yang digunakan untuk menghitung dan mengelola data gejala yang dipilih sesuai dengan kerusakan yang dialami dengan algoritma Certainty Factor yang nantinya akan menghasilkan diagnosa kerusakan dan user akan memperoleh solusi penaganannya. Adapun tampilan keluaran dari form diagnosa adalah sebagai berikut :

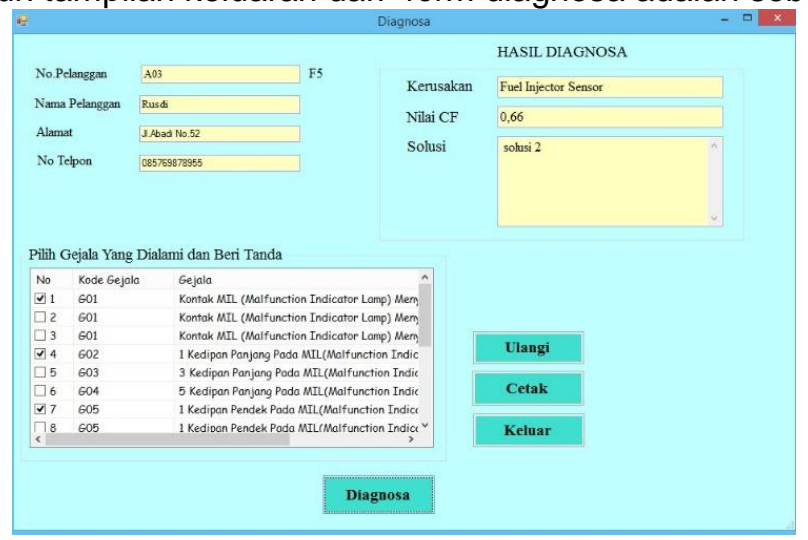

Gambar 4.6 Tampilan Form Diagnosa 


\section{Form Laporan}

Form Laporan adalah form yang menampilkan laporan data hasil diagnosa dan data solusi kerusakan. Adapun tampilan keluaran dari form laporan dapat dilihat pada gambar berikut ini:

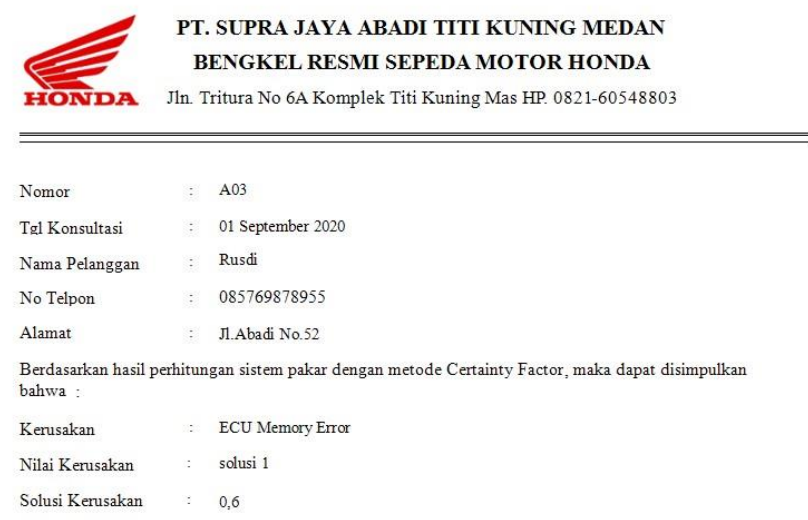

Gambar 4.6 Tampilan Form Laporan

\section{Kesimpulan}

Perancangan sistem pakar mendiagnosa kerusakan ECU (Electronic Control Unit) menggunakan algoritma Certainty Factor yang telah diselesaikan ini dapat diambil beberapa kesimpulan diantaranya adalah:

1. Analisa kerusakan ECU pada motor injeksi dengan algoritma Certainty Factor dengan cara menghitung nilai MB (Measure of Beliefe) dan menghitung MD (Measure of Disbeliefe) pada masing-masing gejala.

2. Penerapan algoritma Certainty Factor untuk mendiagnosa kerusakan ECU (Electronic Control Unit) adalah dengan cara memberi nilai skor MB dan MD untuk tiap-tiap gejala antara 0,1-0,9 untuk masing-masing gejala.

3. Perancangan aplikasi menggunakan UML, sedangkan untuk tampilan aplikasi menggunakan bahasa pemrograman visual, database Acces sebagai tempat penyimpanan data pelanggan,data gejala,data kerusakan dan data diagnosa.

4. Pengujian pada sistem dengan mengimplementasikan data perhitungan pada bab 3 dan hasil perhitungan dari sistem yang diproses dengan Algoritma Certainty Factor hingga sistem menghasilkan perhitungan yang sama dengan data uji manual.

\section{UCAPAN TERIMA KASIH}

Puji syukur dipanjatkan kehadirat Tuhan yang maha esa karena berkat rahmat dan kasihNya, yang masih memberikan kesehatan dan kesempatan sehingga dapat diselesaikan jurnal ilmiah ini dengan baik. ucapan terima kasih ditujukan kepada kedua Orang tua, atas kesabaran, ketabahan serta ketulusan hati memberikan dorongan moril maupun material serta doa yag tiada henti-hentinya. Ucapan terimakasih juga ditujukan untuk pihak-pihak yang telah mengambil bagian dalam penyusunan jurnal ilmiah ini.

\section{REFERENSI}

[1] A. Sartika Wiguna and I. Harianto, "Sepeda Motor Matic Injeksi Menggunakan Metode Forward," SMARTICS J., vol. 3, no. 1, pp. 25-30, 2017.

[2] A. S. Wiguna and I. Harianto, "Sistem Pakar Diagnosa Kerusakan Sepeda Motor Matic Injeksi Menggunakan Metode Forward Chaining Berbasis Android," SMARTICS J., vol. 3, no. 1, pp. 25-30, 2017, doi: 10.21067/smartics.v3i1.1933.

[3] F. Fahmi and M. N. Yuniarto, "Perancangan dan Unjuk Kerja Engine Control Unit ( ECU ) iquteche pada motor Yamaha vixion," vol. 1, no. 1, pp. 1-6, 2013.

[4] K. E. Setyaputri, A. Fadlil, and S. Sunardi, "Analisis Metode Certainty Factor pada Sistem Pakar Diagnosa Penyakit THT," J. Tek. Elektro, vol. 10, no. 1, pp. 30-35, 2018, doi: 10.15294/jte.v10i1.14031.

[5] M. Silmi, E. A. Sarwoko, and F. Chaining, "Sistem pakar berbasis web dan mobile untuk 
mendiagnosa penyakit darah pada manusia dengan menggunakan metode interfensi forward chaining," vol. 4, pp. 31-38, 1960.

[6] M. Arifin, S. Slamin, and W. E. Y. Retnani, "Penerapan Metode Certainty Factor Untuk Sistem Pakar Diagnosis Hama Dan Penyakit Pada Tanaman Tembakau," Berk. Sainstek, vol. 5, no. 1, p. 21, 2017, doi: 10.19184/bst.v5i1.5370.

[7] Yasmiyati, "Sistem Pakar Diagnosis Penyakit Pada Perokok Dengan Metode Forward Chaining Berbasis Web," Paradig. - J. Komput. dan Inform., vol. 19, no. 1, pp. 69-73, 2017, doi: 10.31294/P.V19l1.1782.

[8] A. Sucipto, Y. Fernando, R. I. Borman, and N. Mahmuda, "Penerapan Metode Certainty Factor Pada Diagnosa Penyakit Saraf Tulang Belakang," J. IIm. FIFO, vol. 10, no. 2, p. 18, 2019, doi: 10.22441/fifo.2018.v10i2.002. 